\title{
Consumption of animal-based and processed food associated with cardiovascular risk factors and subclinical atherosclerosis biomarkers in men
}

\author{
(D) Júlio César Acosta-Navarro,3 \\ (iD) Adriana Midori Oki1,3 \\ (1DLuiza Antoniazzi, ${ }^{1,2}$ \\ (D) Maria Aparecida Carlos Bonfim ${ }^{1}$ \\ (iD) Valeria Hong ${ }^{1}$ \\ (D) Maria Cristina de Almeida Gaspar ${ }^{2}$ \\ (iD) Valeria Cristina Sandrim ${ }^{4}$ \\ (iD) Adriana Nogueira ${ }^{1}$ \\ 1. Heart Institute (InCor) of the Hospital das Clínicas of the Faculty of Medicine, USP, São Paulo(SP), Brasil \\ 2. Paulista University (Unip), São Paulo (SP), Brasil \\ 3. Center of Medical Specialties (CEM), Ferraz de Vasconcelos (SP), Brasil \\ 4. Department of Pharmacology, Institute of Biosciences of Botucatu, São Paulo State University (Unesp), Botucatu (SP), Brasil
}

http://dx.doi.org/10.1590/1806-9282.65.1.43

\section{SUMMARY}

OBJECTIVE: To evaluate the frequency of food consumption in apparently healthy men and their association with cardiovascular risk factors and biomarkers of subclinical atherosclerosis.

METHODS: In this observational study, 88 men had their food standard obtained through the food frequency questionnaire (FFQ). Associations of dietary patterns with cardiovascular risk factors, such as anthropometric data, laboratory and clinical evaluations, carotid-femoral arterial stiffness (IMT) and pulse wave velocity were evaluated.

RESULTS: The highest values were observed, for most of the risk factors evaluated, with the highest frequency of weekly consumption of dairy products, meats, sweets, fats, cold meats, sodas, milk and white chocolate; and lower frequency of weekly consumption of fruits, cereals, vegetables, legumes, oilseeds, and soy. There was no significant difference for coffee and dark chocolate

CONCLUSIONS: A diet with high consumption of animal products has a higher correlation with cardiovascular risk factors; the opposite is true for the consumption of plant-based food, associated with the profile of more favorable biomarkers for cardiovascular health and better biochemical and structural parameters.

KEYWORDS: Atherosclerosis. Food Consumption. Pulse Wave Analysis. Vascular Stiffness.

\section{INTRODUCTION}

Chronic non-communicable diseases (CNCD) are the leading cause of disability. Among them are included cardiovascular disease, responsible for $30 \%$ of deaths worldwide. Epidemiological data suggest that individuals who follow diets rich in fruits and vegetables have a lower risk of CNCD and mortality than those who follow diets poor in vegetables'. Several studies have shown a connection between the consumption of meat and hypertension, risk of heart disease, metabolic disorders, and mortality ${ }^{2-9}$. The relationship between food and diseases in groups who follow specific diets, such as vegetarians, have required the attention of scholars. In the past, the fo- 
cus was on evidencing the problems caused by the deficiency of certain nutrients; now, it is evident a tendency to study the possible health benefits of a diet completely or partially plant-based, such as the ovo-lacto vegetarian diet $^{10}$.

Recent studies show the link between diet and nutritional state with the occurrence of $\mathrm{CNCD}^{10,11}$. Despite vast clinical and epidemiological evidence that diet has a direct effect on the onset of chronic diseases, the mechanisms of action are not yet clearly understood, especially regarding cardiovascular risk $^{12,13}$. Furthermore, some studies have investigated the relationship between the consumption of certain nutrients or food and the intima-media thickness ${ }^{14,15}$ and the pulse wave velocity ${ }^{16}$.

Due to the scientific interest in food consumption, healthy diet, cardiovascular health, and the scarcity of studies that carry out that analysis, the objective of this study was to assess the frequency of food consumption in men who were apparently healthy and its link with cardiovascular risk.

\section{METHODS}

\section{Study population}

In this cross-sectional observational study, 745 adult volunteers were recruited in the city of São Paulo, Brazil, through social activities and internet publicity, initially between October 2012 and June 2013. The participants filled out questionnaires on family and personal medical history, diet preferences, physical activity, formal education, and personal data. The exclusion criteria were: 1 ) female; 2) under 35 years old; 3) history of diabetes; 4) history of dyslipidemia; 5) history of cardiovascular or cerebrovascular diseases; 6) history of hypertension or of use of antihypertensive medication; and 7) smoking. All individuals that declared to be smokers or "occasional smokers," or who had quit smoking one month before the interview were considered smokers. The sample consisted of men who were apparently healthy in order to prevent confounding risk factors for subclinical atherosclerosis.

Healthy participants who were $\geq 35$ years old were allocated into two groups - VEG and OMNI -, according to their diets. VEG men were defined as having had a vegetarian diet free of meat, fish, and poultry for at least four years; these men could be ovo-lacto vegetarian (consumption of eggs, milk and dairy), lacto-vegetarians (consumption of milk and dairy), or vegan (no consumption of eggs, milk, or dairy). OMNI men were defined as those who consume any type of meat, at least five portions or more per week. During the period from July 2013 to January 2014, after the inclusion and exclusion criteria were applied, 88 men, $\geq 35$ years old, apparently healthy were included in the study (44 vegetarians and 44 omnivores). The original study design had the intention of studying the link between a vegetarian and omnivore diet on cardiovascular risk factors; however, in this study, our strategy was to consider both groups as a whole. The research committee of the Heart Institute (InCor) of the Hospital of the Faculty of Medicine of the University of São Paulo approved the protocol of the study, and all participants signed an Informed Consent Form to participate in the study.

Laboratory and clinical analysis, ultrasonography of the carotid, pulse wave velocity (PWV) The methodology of these variables is described in the previous publication of the CARVOS Study ${ }^{17}$.

\section{Anthropometric assessment}

For the anthropometric assessment, we used the Body Mass Index (BMI) and the bioelectrical impedance analysis (BIA). To assess the level of physical activity we used the International Physical Activity Questionnaire-Short Form (Ipaq). The methodology is described in the CARVOS ${ }^{18}$ study on body composition.

The assessment of the frequency of food consumption

The individuals were interviewed, and a food frequency questionnaire (FFQ) was applied to assess the pattern of consumption of food groups.

Each individual was asked: Over the last seven days, in how many days did you consume the following food or beverages? The following alternatives were possible: Did not eat over the last seven days; 1 day over the last seven days; 2 days over the last seven days; 3 days over the last seven days; 4 days over the last seven days; 5 days over the last seven days; 6 days over the last seven days; and all seven days.

The food groups assessed were: 1. Grains, tubers, and roots (rice, corn, bread, cookies, pasta, pastry, potato, manioc); 2. Leafy greens (chard, lettuce, broccoli, collard greens, kale, spinach, cabbage, arugula, etc.); 3. Vegetables (pumpkins, beet, carrot, chayote, cucumbers, tomato, etc.); 4. Fresh fruits (pineap- 
ple, banana, apple, papaya, strawberry, grape, fruit salad, etc.); 5. Legumes (beans, peas, lentils, chickpeas, soy); 6. Oilseeds (nuts, almonds, pistachios, linseed, sunflower seeds); 7. Dairy products (milk, yogurt, and cheese); 8. Meat (poultry, beef, pork, game - such as rabbit and pheasant, etc.); 9. Fish and seafood (shrimp, crab, lobster, etc.); 10. Eggs (fried, boiled, poached, etc.). 11. Cold meats (sausage, salami, hamburger, bologna, ham, turkey breast, etc.); 12. Soy-based food and drinks (soy-based drinks, textured vegetable protein, etc.); 13. Fats (fried food, such as potato or manioc, croquettes, hand pies); 14 . Sweets (candy, gum, candied fruit, etc.); 15. Soda (not including diet or light ones); 16. Milk Chocolate; 17. Dark chocolate; 18 . White chocolate; and 19. Coffee.

The instrument of food consumption frequency used was based on Sisvan, which according to the Ministry of Health ${ }^{19}$ is similar to versions used in research for monitoring practices that pose a risk to health, such as the North-American Youth Risk Behavior Survey - YRBS, carried out by the Center for Disease Control and Prevention - CDC. Moreover, we considered the questionnaire used in Vigitel (Vigilance of Chronic Diseases through Phone Survey), conducted by the Department of Health Vigilance of the Ministry of Health in Brazil.

In this study, the frequency of food consumption was categorized in 0-3 times per week and 4-7 times per week; and the tables and images were divided in plant-based, animal-based, and processed/homemade food.

\section{Statistical analysis}

The variables analyzed in this study were: systolic blood pressure (SBP), diastolic blood pressure (DBP), thickness of the intima-media thickness (IMT), pulse wave velocity (PWV), Framingham risk score, percentage of lean body mass (\%LBM), percentage of body fat $(\% \mathrm{BF})$, percentage of total body water (\%TBW), total cholesterol (TC), low-density lipoprotein (LDL), TC/HDL ratio, triglycerides (TG), glucose (GL), measurement of glycated hemoglobin (Glyc-Hb), apolipoprotein B (ApoB), C-reactive protein (CRP).

The continuous variables are presented as Standard Deviation (SD) \pm Means. T-tests and chi-square tests were used to test differences in numeric and nominal variables.

All the calculations were made using the Stata software, version 10.0.
TABLE 1. Mean values of cardiovascular risk factors, according to the frequency of consumption of products of plant origin.

\begin{tabular}{|c|c|c|c|}
\hline \multicolumn{4}{|c|}{ Frequency of consumption } \\
\hline Variable & 0 to $3 x /$ week & 4 to $7 x /$ week & $P$ value \\
\hline \multicolumn{4}{|c|}{ Fruits } \\
\hline & $\mathrm{n}=18$ & $n=70$ & \\
\hline Diastolic blood pressure & $85.5( \pm 11.49)$ & $78.40( \pm 9.63)$ & 0.004 \\
\hline Glycaemia & $102.94( \pm 20.33)$ & $97.90( \pm 7.56)$ & 0.049 \\
\hline PCR & $4.56( \pm 9.55)$ & $1.74( \pm 2.72)$ & 0.016 \\
\hline \multicolumn{4}{|c|}{ Cereals } \\
\hline & $n=3$ & $n=85$ & \\
\hline Total cholesterol & $243.67( \pm 37.81)$ & $189.60( \pm 38.42)$ & 0.009 \\
\hline LDL & $163.00( \pm 29.82)$ & $117.73( \pm 33.14)$ & 0.011 \\
\hline Percentage of lean mass & $71.80( \pm 7.92)$ & $78.94( \pm 5.73)$ & 0.019 \\
\hline Percentage of fat mass & $28.20( \pm 7.92)$ & $21.12( \pm 5.97)$ & 0.024 \\
\hline Percentage of water & $51.88( \pm 5.99)$ & $57.42( \pm 4.65)$ & 0.024 \\
\hline Framingham score & $8.33( \pm 6.81)$ & $3.74( \pm 4.45)$ & 0.043 \\
\hline \multicolumn{4}{|c|}{ Vegetables } \\
\hline & $n=22$ & $n=66$ & \\
\hline Diastolic blood pressure & $83.41( \pm 11.75)$ & $78.67( \pm 9.68)$ & 0.031 \\
\hline Total cholesterol/HDL & $4.83( \pm 1.45)$ & $4.17( \pm 1.28)$ & 0.021 \\
\hline Triglycerides & $160.77( \pm 77.79)$ & $117.15( \pm 63.73)$ & 0.005 \\
\hline Glycated haemoglobin & $5,57( \pm 0.48)$ & $5.39( \pm 0.34)$ & 0.029 \\
\hline Percentage of lean mass & $76.76( \pm 6.26)$ & $79.32( \pm 5.69)$ & 0.041 \\
\hline \multicolumn{4}{|c|}{ Greens } \\
\hline & $n=20$ & $n=68$ & \\
\hline Diastolic blood pressure & $83.30( \pm 11.79)$ & $78.84( \pm 9.79)$ & 0.045 \\
\hline Total cholesterol/HDL & $4.88( \pm 1.42)$ & $4.17( \pm 1.29)$ & 0.019 \\
\hline LDL & $43.05( \pm 10.47)$ & $47.54( \pm 10.37)$ & 0.046 \\
\hline Triglycerides & $157.70( \pm 77.39)$ & $119.34( \pm 65.33)$ & 0.014 \\
\hline Glycaemia & $103.10( \pm 18.67)$ & $97.63( \pm 7.61)$ & 0.028 \\
\hline Glycated haemoglobin & $5.60( \pm 0.51)$ & $5.39( \pm 0.33)$ & 0.013 \\
\hline Percentage of fat mass & $23.85( \pm 6.64)$ & $20.66( \pm 5.84)$ & 0.022 \\
\hline Percentage of water & $55.48( \pm 3.48)$ & $57.73( \pm 5.00)$ & 0.035 \\
\hline \multicolumn{4}{|c|}{ Legumes } \\
\hline & $n=19$ & $n=69$ & \\
\hline Total cholesterol/HDL & $4.79( \pm 1.54)$ & $4.21( \pm 1.27)$ & 0.046 \\
\hline LDL & $131.32( \pm 28.57)$ & $115.96( \pm 34.68)$ & 0.04 \\
\hline \multicolumn{4}{|c|}{ Oilseeds } \\
\hline & $n=54$ & $n=34$ & \\
\hline Systolic blood pressure & $126.37( \pm 15.12)$ & $121.15( \pm 10.87)$ & 0.042 \\
\hline Diastolic blood pressure & $81.57( \pm 10.57)$ & $77.12( \pm 9.57)$ & 0.024 \\
\hline Total cholesterol & $197.54( \pm 35.94)$ & $181.76( \pm 43.23)$ & 0.033 \\
\hline Total cholesterol/HDL & $4.58( \pm 1.24)$ & $3.94( \pm 1.42)$ & 0.013 \\
\hline LDL & $124.11( \pm 29.73)$ & $110.79( \pm 38.58)$ & 0.031 \\
\hline Triglycerides & $138.67( \pm 65.43)$ & $111.21( \pm 73.82)$ & 0.035 \\
\hline Glycated haemoglobin & $5.50( \pm 0.43)$ & $5.33( \pm 0.28)$ & 0.021 \\
\hline IMT & $662.04( \pm 114.88)$ & $572.35( \pm 98.35)$ & 0 \\
\hline VOP & $7.62( \pm 0.85)$ & $7.04( \pm 0.75)$ & 0 \\
\hline Framingham score & $4.68( \pm 5.34)$ & $2.65( \pm 2.58)$ & 0.02 \\
\hline \multicolumn{4}{|c|}{ Soy and derivatives } \\
\hline & $\mathrm{n}=73$ & $n=15$ & \\
\hline Total cholesterol/HDL & $4.48( \pm 1.35)$ & $3.64( \pm 1.13)$ & 0.013 \\
\hline LDL & $122.04(3 \pm 3.24)$ & $105.80( \pm 34.97)$ & 0.045 \\
\hline
\end{tabular}




\section{RESULTS}

In the present study, we analyzed 88 individuals, with a mean age of $46.1( \pm 8.68)$. According the body mass index, $54.5 \%(\mathrm{n}=48)$ had adequate weight and $29.5 \%(\mathrm{n}=26)$ presented risk of obesity. Regarding the level of formal education, $47.7 \%(n=42)$ had higher education, and 33\% secondary education. Most individuals, $69.3 \%(\mathrm{n}=61)$ had a high level of physical activity.

In Table 1, which shows the variables with plantbased food, we can see that those who eat fruits 4-7 times a week have lower glucose, CRP, and DBP values. For grains, those who consume it more times per week have lower values for LDL, TC, and Framingham risk score. Individuals who eat vegetables more times per week have lower TG, glyc-Hb, TC/ HDL, DBP. Those who eat leafy greens more times per week have lower values for DBP, TC/HDL, TG, GL, glyc-Hb, and higher HDL for legumes, those who consume them more times per week have lower TC/ HDL and LDL. As for oilseeds, those who consume them more times per week have lower SBP, DBP, TC,

TABLE 2. Mean values of cardiovascular risk factors, according to frequency of consumption of products of animal origin.

\begin{tabular}{|c|c|c|c|}
\hline \multicolumn{4}{|c|}{ Frequency of consumption } \\
\hline \multirow[t]{3}{*}{ Variable } & 0 to $3 x /$ week & 4 to $7 x /$ week & P value \\
\hline & \multicolumn{2}{|l|}{ Dairy } & \\
\hline & $n=36$ & $n=52$ & \\
\hline $\mathrm{HDL}$ & $49.19( \pm 11.35)$ & $44.67( \pm 9.56)$ & 0.023 \\
\hline Triglycerides & $109.86( \pm 63.41)$ & $140.65( \pm 71.62)$ & 0.02 \\
\hline Glycated haemoglobin & $5.34( \pm 0.33)$ & $5.51( \pm 0.41)$ & 0.02 \\
\hline Haemoglobin & $15.89(0.96)$ & $15.45( \pm 0.95)$ & 0.022 \\
\hline \multirow[t]{3}{*}{ Framingham score } & $2.92( \pm 3.89)$ & $4.58( \pm 4.90)$ & 0.046 \\
\hline & \multicolumn{2}{|l|}{ Meats } & \\
\hline & $n=50$ & $n=38$ & \\
\hline Total Cholesterol/HDL & $3.98( \pm 1.27)$ & $4.80( \pm 1.31)$ & 0.002 \\
\hline Triglycerides & $114.66( \pm 71.06)$ & $145.68( \pm 64.57)$ & 0.018 \\
\hline Glycaemia & $95.71( \pm 7.36)$ & $102.97( \pm 13.92)$ & 0.001 \\
\hline Glycated haemoglobin & $5.34( \pm 0.28)$ & $5.57( \pm 0.47)$ & 0.002 \\
\hline Systolic blood pressure & $120.28( \pm 11.56)$ & $129.71( \pm 14.81)$ & 0 \\
\hline Diastolic blood pressure & $76.20( \pm 8.43)$ & $84.66( \pm 10.83)$ & 0 \\
\hline Percent of fat mass & $19.73( \pm 4.74)$ & $23.61( \pm 7.11)$ & 0.001 \\
\hline Water percentage & $58.17( \pm 4.75)$ & $55.95( \pm 4.57)$ & 0.017 \\
\hline IMT & $596.10( \pm 97.10)$ & $668.55( \pm 128.52)$ & 0.001 \\
\hline \multirow[t]{3}{*}{ VOP } & $7.21( \pm 0.85)$ & $7.64( \pm 0.83)$ & 0.009 \\
\hline & \multicolumn{2}{|l|}{ Eggs } & \\
\hline & $n=74$ & $n=11$ & \\
\hline Percentage of fat mass & $20.91( \pm 5.76)$ & $24.44( \pm 7.84)$ & 0.037 \\
\hline
\end{tabular}

TC/HDL, LDL, TG, Glyc-Hb, IMT, PWV, and Framingham score. For soy, lower TC/HDL and LDL.

The group of individuals that indicated the highest frequency of consumption of dairy products presented lower values for HDL, and HB; and higher values for TG, Glyc-Hb, and Framingham score. In the category of greater frequency of consumption of meats, we found higher values for TC/HDL, TG, GL, Glyc$\mathrm{Hb}$, SBP, DBP, PWV, and IMT. It was not possible to carry out the analysis of fish consumption for only two men in the sample indicated a regular consumption of the item from 4-7 times per week (Table 2).

For the consumption of sweets, higher TC/HDL, TG, ApoB; and lower HDL. For fat, higher DBP, SBP, TC, TC/HDL, TG, GL, Glyc-Hb, HB, Apo B, CRP. For cold meats, higher GL and CRP. For sodas, higher DBP, TC/HDL, LDL, TG, GL, Apo B, CRP, IMT. For milk chocolate, higher SBP and Glyc-Hb. For white chocolate, higher Glyc-Hb.

The pattern observed in most risk factors assessed was of higher values for higher weekly consumption of sweets, fats/fried foods, cold meats, sodas, white and milk chocolate. There was no significant difference for coffee and dark chocolate (Table 3).

Regarding body composition, we found that those who consume more grains more times per week have lower \%BF and higher \%LBM and water; those who eat vegetables more often have higher \%LBM; and those who consume more leafy greens have lower \%BF and higher \%water (Figure 1). As for animal-based products, for a more often consumption of meat we found a higher $\% \mathrm{BF}$ and lower water; for eggs, higher \%BF (Figure 2). The group of individuals the indicated a higher frequency for the consumption of sweets presented higher \%BF; for fats/fried food, sodas, milk, and white chocolate, we found higher $\% \mathrm{BF}$, and lower \%LBM and water (Figure 3).

\section{DISCUSSION/CONCLUSION}

There are many clinical and epidemiological studies on the influence of diet energy and nutrients over the health state and incidence of diseases. However, individuals do not consume nutrients in isolation but combined in the food that makes up their diet patterns $^{19}$. In the combination of macro and micronutrients, antioxidants and bioactive substances present in food can have a synergy effect in the organism, with a different effect from isolated nutrients. In this context, the present study on the influence of the 
TABLE 3. Mean values of cardiovascular risk factors, according to frequency of consumption of sweets, fats and ultraprocessed foods.

\begin{tabular}{|c|c|c|c|}
\hline \multirow[b]{2}{*}{ Variable } & \multicolumn{3}{|c|}{ Frequency of consumption } \\
\hline & 0 to $3 x /$ weeks & 4 to $7 x /$ week & P Value \\
\hline & \multicolumn{3}{|l|}{ Sweets } \\
\hline & $n=60$ & $n=28$ & \\
\hline Total Cholesterol/HDL & $4.13( \pm 1.20)$ & $4.77( \pm 1.54)$ & 0.018 \\
\hline $\mathrm{HDL}$ & $48.27( \pm 10.76)$ & $42.79( \pm 9.04)$ & 0.01 \\
\hline Triglycerides & $119.17( \pm 66.36)$ & $147.11( \pm 73.98)$ & 0.039 \\
\hline Apob & $0.91( \pm 0.27)$ & $1.03( \pm 0.29)$ & 0.028 \\
\hline \multirow[t]{3}{*}{ Percentage of fat mass } & $20.62( \pm 5.96)$ & $23.00( \pm 6.28)$ & 0.047 \\
\hline & \multicolumn{3}{|l|}{ Fats/Fried } \\
\hline & $n=74$ & $n=14$ & \\
\hline Systolic blood pressure & $123.09( \pm 13.39)$ & 131. $00( \pm 14.56)$ & 0.024 \\
\hline Diastolic blood pressure & $78.05( \pm 8.55)$ & $89.36( \pm 13.95)$ & 0 \\
\hline Total cholesterol & $187.66( \pm 39.93)$ & 211. $43( \pm 30.74)$ & 0.019 \\
\hline Total Cholesterol/HDL & $4.18( \pm 1.27)$ & $5.13( \pm 1.47)$ & 0.007 \\
\hline Triglycerides & $119.45( \pm 64.25)$ & $173.57( \pm 81.62)$ & 0.003 \\
\hline Glycaemia & $97.85( \pm 7.51)$ & $104.29( \pm 22.10)$ & 0.024 \\
\hline Glycated haemoglobin & $5.40( \pm 0.34)$ & $5.61( \pm 0.57)$ & 0.031 \\
\hline Haemoglobin & $15.53( \pm 0.97)$ & $16.27( \pm 0.77)$ & 0.01 \\
\hline Apob & $0.92( \pm 0.28)$ & $1.09( \pm 0.19)$ & 0.019 \\
\hline PCR & $1.87( \pm 2.79)$ & $4.65( \pm 10.81)$ & 0.028 \\
\hline Percentage of lean mass & $79.16( \pm 5.84)$ & $75.82( \pm 5.74)$ & 0.034 \\
\hline Percentage of fat mass & $20.91( \pm 6.11)$ & $24.18( \pm 5.74)$ & 0.043 \\
\hline \multirow[t]{3}{*}{ Percentage of water } & $57.65(4.82)$ & $54.62( \pm 3.69)$ & 0.02 \\
\hline & \multicolumn{3}{|l|}{ Sausages } \\
\hline & $n=76$ & $\mathrm{n}=11$ & \\
\hline Glycaemia & $98.05( \pm 7.70)$ & $104.64( \pm 24.58)$ & 0.034 \\
\hline \multirow[t]{3}{*}{ PCR } & $1.93( \pm 2.79)$ & $5.05( \pm 12.21)$ & 0.026 \\
\hline & \multicolumn{3}{|l|}{ Soft Drinks } \\
\hline & $\mathrm{n}=79$ & $n=9$ & \\
\hline Diastolic blood pressure & $78.78( \pm 9.66)$ & $89.22( \pm 12.30)$ & 0.001 \\
\hline Total cholesterol/HDL & $4.23( \pm 1.32)$ & $5.24( \pm 1.27)$ & 0.016 \\
\hline LDL & $116.77( \pm 33.43)$ & $141.22( \pm 31.55)$ & 0.019 \\
\hline Triglycerides & $121.20( \pm 66.14)$ & $188.22( \pm 75.01)$ & 0.002 \\
\hline Glycaemia & $98.15( \pm 7.57)$ & $105.22( \pm 27.59)$ & 0.037 \\
\hline Apob & $0.92( \pm 0.27)$ & $1.20( \pm 0.21)$ & 0.001 \\
\hline PCR & $1.84( \pm 2.74)$ & $6.50( \pm 13.31)$ & 0.003 \\
\hline Percentage of lean mass & $79.14( \pm 5.71)$ & 74. $32( \pm 6.33)$ & 0.013 \\
\hline Percentage of fat mass & $20.93( \pm 5.98)$ & $25.67( \pm 6.33)$ & 0.018 \\
\hline Percentage of water & $57.57( \pm 4.72)$ & $53.86( \pm 4.17)$ & 0.017 \\
\hline \multirow[t]{3}{*}{ IMT } & $618.26( \pm 114.05)$ & $707.50( \pm 115.97)$ & 0.014 \\
\hline & \multicolumn{3}{|l|}{ Milk Chocolate } \\
\hline & $n=79$ & \multicolumn{2}{|l|}{$n=9$} \\
\hline Systolic blood pressure & $123.53( \pm 13.57)$ & $131.56( \pm 14.61)$ & 0.049 \\
\hline Glycated haemoglobin & $5.4(0.37)$ & $5.72(0.40)$ & 0.009 \\
\hline Percentage of lean mass & $79.20( \pm 5.68)$ & $74.38( \pm 6.40)$ & 0.009 \\
\hline Percentage of fat mass & $20.87( \pm 5.95)$ & $25.61( \pm 6.39)$ & 0.013 \\
\hline \multirow[t]{3}{*}{ Percentage of water } & $57.62( \pm 4.70)$ & $53.90( \pm 4.29)$ & 0.013 \\
\hline & \multicolumn{3}{|c|}{ White Chocolate } \\
\hline & $n=83$ & $n=2$ & \\
\hline Glycated haemoglobin & $5.42( \pm 0.38)$ & $5.95( \pm 0.21)$ & 0.029 \\
\hline Percentage of lean mass & $78.92( \pm 5.79)$ & $69.35( \pm 2.33)$ & 0.011 \\
\hline Percentage of fat mass & $21.15( \pm 6.03)$ & $30.60( \pm 2.40)$ & 0.015 \\
\hline Percentage of water & $57.38( \pm 4.72)$ & $50.69( \pm 0.37)$ & 0.024 \\
\hline
\end{tabular}

consumption of food groups over cardiovascular risk factors can be considered promising.

This way, some studies have verified an association between diet patterns and chronic diseases, such as obesity ${ }^{20}$, endothelial function, and inflammation $^{21}$, and some types of cancer, amongst them oral $^{22}$, gastric ${ }^{23}$, and cerebral ${ }^{24}$.

In the present study, we found significant differences in the cardiovascular risk factors assessed according to the frequency of consumption of specific food items, with the exception of fish, coffee, and dark chocolate. Some studies have investigated food consumption and cardiovascular risk factors. Kerver et al. ${ }^{25}$ found that the food pattern named "Western," characterized by the high consumption of processed meats, eggs, red meat, and dairy products with high fat levels, is positively associated with serum levels of insulin, C-peptide, and glycated hemoglobin. As for the pattern know as "Healthy American" (high amounts of leafy green vegetables, salad dressing, tomatoes, and other vegetables, and tea), there was no correlation found with the biomarkers analyzed.

In the study by Centritto et al. ${ }^{26}$, three patterns of diet were categorized. The "Olive Oil and Vegetables" pattern, characterized by the high intake of olive oil, vegetables, soup, fruit, and fish, was associated with relatively low values of glucose, fats, CRP, arterial pressure, and individual cardiovascular risk scores. The "Meats and Pasta" pattern, characterized by a high intake of pasta, tomato sauce, red meat, animal fat, and alcohol, was positively associated with blood glucose, fats, CRP, and cardiovascular risk scores. The "Eggs and Sweets" pattern, characterized by positive loads of eggs, processed meats, margarine, butter, sugar, and sweets, was associated with high CRP values.

There was also a study conducted with the Brazilian population. Olinto et al. ${ }^{27}$ classified the food consumption into two patterns: the first one, the Average Brazilian, characterized by sugar, white bread, coffee, margarine/butter, rice, and black beans. The second, the Processed Food, was characterized by red and processed meats, salty snacks, french fries, beer, soda, and other processed food. The Average Brazilian was inversely associated with values of LDL, HDL, and total cholesterol in men. Amongst women, they found tendencies of an inverse association with SBP, DBP, LDL, HDL, and TC. The patter of Processed Food was positively associated with values of LDL, HDL, and TC amongst men. Amongst wom- 
FIGURE 1. MEAN VALUES OF BODY COMPOSITION ACCORDING TO THE FREQUENCY OF CONSUMPTION OF PLANT-BASED FOOD.

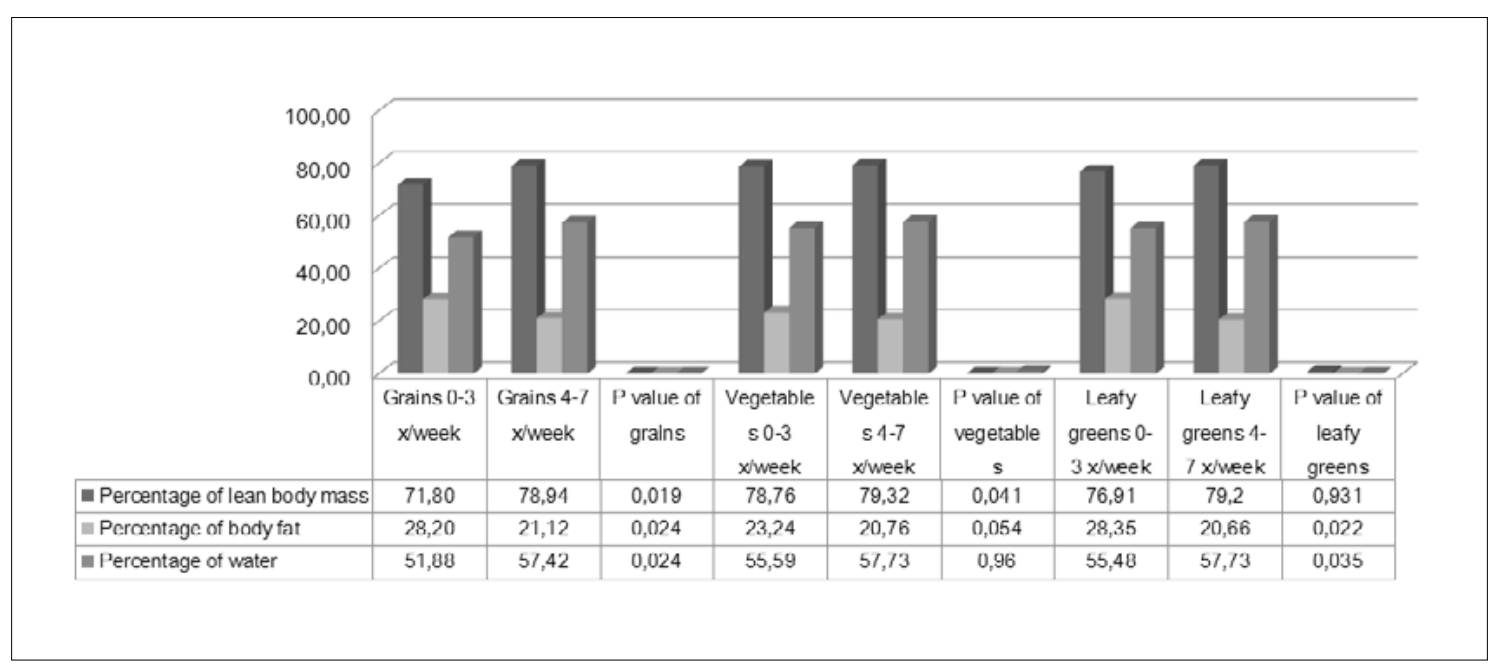

FIGURE 2. MEAN VALUES OF BODY COMPOSITION, ACCORDING TO FREQUENCY OF CONSUMPTION OF PRODUCTS OF ANIMAL ORIGIN.

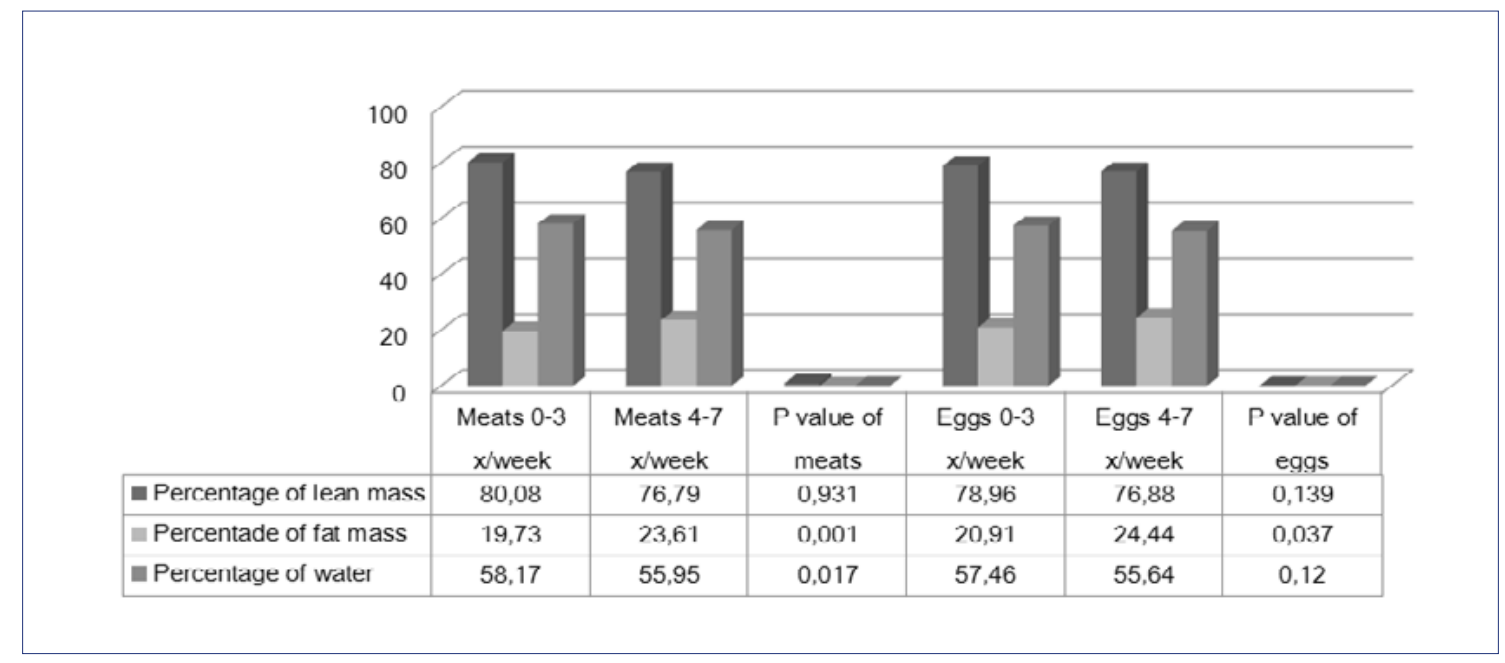

FIGURE 3. MEAN VALUES OF BODY COMPOSITION, ACCORTDING TO FREQUENCY OF ULTRAPROCESSED FOOD.

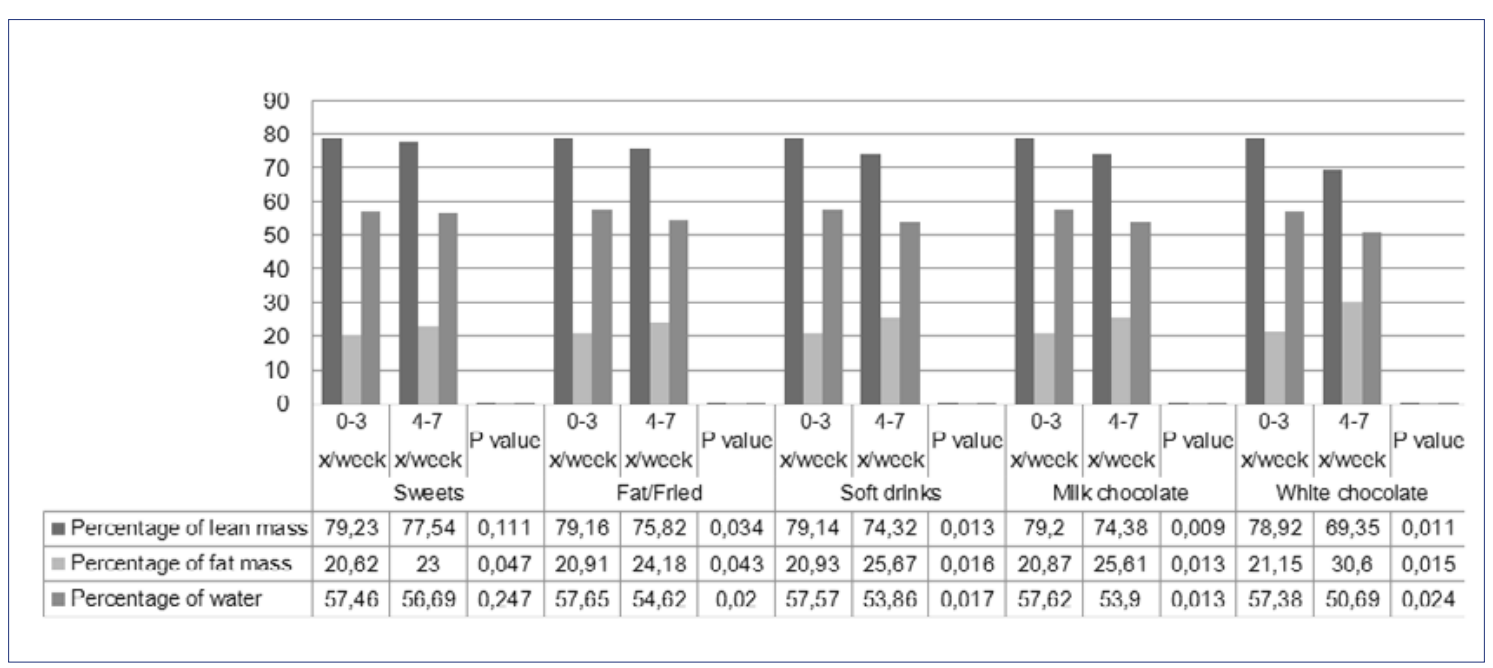


en, the Processed Food pattern was not significantly associated with cardiovascular risk factors.

In the clinical practice, the assessment of food consumption has the purpose of helping with the development and implementation of nutritional planning $^{28}$. There are several methods for assessing food intake and nutrient consumption, and it is important to choose the one that aims at promoting health, preventing injuries, and adjusting the nutritional state of the patient. In this sense, the method of food consumption or food groups is the food frequency questionnaire $(\mathrm{FFQ})^{28}$.

The FFQ is considered to be the most practical and informative method for assessment in studies that investigate the connection between diet and clinical outcomes, usually associated with $\mathrm{CNCD}^{28}$.

The fact that this is a cross-sectional study compromises its causality proof. In addition, there is a re- stricted number of individuals. However, the sample is highly homogenized in sex and age, and reproducible methods were used.

The present study was conducted with a sample of apparently healthy men who make up a large portion of the population and which is of great interest in terms of prevention of chronic diseases since these are associated with inadequate food consumption parameters.

\section{CONCLUSION}

In the present study, higher consumption of plantbased food was less associated with cardiovascular risk factors; the contrary was found for animal-based food, sweets, fats, and ultra-processed food, with a higher association to cardiovascular risk factors, the higher the weekly frequency of their consumption.

\section{RESUMO}

OBJETIVO: Avaliar a frequência do consumo alimentar de indivíduos homens aparentemente saudáveis e a associação desta com fatores de risco cardiovascular e biomarcadores de aterosclerose subclínica.

MÉTODOS: Neste estudo observacional, 88 homens tiveram o padrão alimentar obtido por meio do questionário de frequência alimen$\operatorname{tar}($ QFA). Foram avaliadas as associações dos padrões alimentares com os fatores de risco cardiovascular, como dados antropométricos, avaliações laboratoriais e clínica, rigidez arterial determinada pela carótida-femoral (IMT) e velocidade da onda de pulso (VOP).

RESULTADOS: O padrão observado para a maioria dos fatores de risco avaliados foi de valores mais altos, segundo maior frequência de consumo semanal de lácteos, carnes, doces, gorduras/frituras, embutidos, refrigerantes, chocolates ao leite e branco; e de menor frequência de consumo semanal de frutas, cereais, legumes, verduras, leguminosas, oleaginosas e soja. Não houve diferença significativa para café e chocolate amargo.

CONCLUSÕES: Uma dieta com alto consumo de produtos animais apresenta maior correlação com fatores de risco cardiovascular, sendo o oposto para o consumo de alimentos de origem vegetal, associado ao perfil de biomarcadores de saúde cardiovascular mais favorável e melhores parâmetros bioquímicos e estruturais.

PALAVRAS-CHAVE: Aterosclerose. Consumo de alimentos. Análise de onda de pulso. Rigidez vascular.

\section{REFERENCES}

1. Silva LB, Silva SS, Marcílio AG, Pierin AM. Prevalence of arterial hypertension among Seventh-Day Adventists of the São Paulo state capital and inner area. Arq Bras Cardiol. 2012;98(4):329-37.

2. Acosta-Navarro JC, Prado SMC, Sanchez DE, Ayala CC, Cabezas JT, Mejia ZP, et al. Pressão sanguínea, perfil lipídico e outros parâmetros bioquímicos entre peruanos vegetarianos, semi-vegetarianos e omnívoros. O estudo Lima. An Paul Med Cir. 1998;125(3):87-101.

3. Acosta-Navarro JC, Prado SC, Guimarães G, Martins M, Caramelli B. Vegetarians and semi-vegetarians are less exposed to cardiovascular risk factors. Int | Atheroscler. 2006;1(1):48-54.

4. Navarro JA, Caramelli B. Vegetarians from Latin America. Am | Cardiol. 2010;105(6):902.

5. Craig WJ. Nutrition concerns and health effects of vegetarian diets. Nutr Clin Pract. 2010;25(6):613-20.

6. Sticher MA, Smith CB, Davidson S. Reducing heart disease through the vegetarian diet using primary prevention. I Am Acad Nurse Pract. 2010;22(3):134-9.
7. Huang T, Yang B, Zheng J, Li G, Wahlqvist ML, Li D. Cardiovascular disease mortality and cancer incidence in vegetarians: a meta-analysis and systematic review. Ann Nutr Metab. 2012;60(4):233-40.

8. Pettersen B|, Anousheh R, Fan |, |aceldo-Sieg| K, Fraser GE. Vegetarian diets and blood pressure among white subjects: results from the Adventist Health Study-2 (AHS-2). Public Health Nutr. 2012;15(10):1909-16.

9. Navarro JC, Prado SM, Cárdenas PA, Santos RD, Caramelli B. Pre-historic eating patterns in Latin America and protective effects of plant-based diets on cardiovascular risk factors. Clinics (Sao Paulo). 2010;65(10):1049-54.

10. Brasil. Ministério da Saúde. Departamento de Atenção Básica. Guia alimentar para a população brasileira. 2ª ed. Brasília: Ministério da Saúde; 2014.

11. Casado L, Vianna LM, Thuler LCS. Fatores de risco para doenças crônicas não transmissíveis no Brasil: uma revisão sistemática. Rev Bras Cancerol. 2009;55(4):379-88.

12. Dourado KF, Campos FACS, Rojas HF, Simões SKS, Siqueira LP. Estado nutricional, estilo de vida e risco cardiovascular de ovolactovegetarianos e onívoros. ALAN. 2010;60(3):220-6. 
13. Teixeira RCMA, Molina MCB, Zandonade E, Mill IG Cardiovascular risk in vegetarians and omnivores: a comparative study. Arq Bras Cardiol. 2007;89(4):237-44

14. Sala-Vila A, Romero-Mamani ES, Gilabert R, Núñez I, de la Torre R, Corella $D$, et al. Changes in ultrasound-assessed carotid intima-media thickness and plaque with a Mediterranean diet: a substudy of the PREDIMED trial. Arterioscler Thromb Vasc Biol. 2012;34(2):439-45.

15. Cai Y, Guo K, Chen C, Wang P, Zhang B, Zhou Q, et al. Soya isoflavone consumption in relation to carotid intima-media thickness in Chinese equo excretors aged 40-65 years. Br J Nutr. 2012;108(9):1698-704.

16. Chan HT, Chan YH, Yiu KH, Li SW, Tam S, Lau CP, et al. Worsened arteria stiffness in high-risk cardiovascular patients with high habitual carbohydrate intake: a cross-sectional vascular function study. BMC Cardiovasc Disord. 2014;14:24.

17. Acosta-Navarro |, Antoniazzi L, Oki AM, Bonfim MC, Hong V, Acosta-Cardenas $P$, et al. Reduced subclinical carotid vascular disease and arterial stiffness in vegetarian men: The CARVOS Study. Int | Cardiol. 2017;230:562-6.

18. Acosta-Navarro IC, Oki AM, Gouveia LAG, Hong V, Bonfim MC, Acosta-Cardenas $P$, et al. Healthier body composition in vegetarian men compared to omnivorous men. J Nutr Food Sci. 2016;6:529.

19. Brasil. Ministério da Saúde. Secretaria de Atenção à Saúde. Departamento de Atenção Básica. Protocolos do Sistema de Vigilância Alimentar e Nutricional - SISVAN na assistência à saúde. Brasília: Ministério da Saúde; 2008

20. Sichieri R. Dietary patterns and their associations with obesity in the Brazilian city of Rio de Janeiro. Obes Res. 2002;10(1):42-8.
21. Thomazella MCD. Efeito da dieta tipo Mediterrânea na função endotelial e inflamação da aterosclerose: estudo comparativo com a dieta TLC (Therapeutic Lifestyle Changes, no NCEP-ATPIII) [Tese de Doutorado]. São Paulo: Faculdade de Medicina, Universidade de São Paulo; 2010. 144p.

22. Marchioni DM, Fisberg RM, Góis Filho JF, Kowalski LP, Carvalho MB Abrahão M, et al. Dietary patterns and risk of oral cancer: a case-control study in São Paulo, Brazil. Rev Saude Publica. 2007;41(1):19-26.

23. Resende ALS, Mattos IE, Koifman S. Dieta e câncer gástrico: aspectos históricos associados ao padrão de consumo alimentar no estado do Pará. Rev Nutr. 2006;19(4):511-9.

24. Albuquerque RCR, Monteiro GTR, Pereira RA, Koifman S. Padrões dietéticos e tumores cerebrais: estudo caso-controle no Rio de Janeiro. Cad Saúde Colet. 2012;20(3):271-9.

25. Kerver JM, Yang EJ, Bianchi L, Song WO. Dietary patterns associated with risk factors for cardiovascular disease in healthy US adults. Am | Clin Nutr. 2003;78(6):1103-10

26. Centritto F, lacoviello L, di Giuseppe R, De Curtis A, Costanzo S, Zito F, et al; Moli-sani Investigators. Dietary patterns, cardiovascular risk factors and C-reactive protein in a healthy Italian population. Nutr Metab Cardiovasc Dis. 2009;19(10):697-706

27. Olinto MT, Gigante DP, Horta B, Silveira V, Oliveira I, Willett W. Major dietary patterns and cardiovascular risk factors among young Brazilian adults. Eur | Nutr. 2012;51(3):281-91.

28. Fisberg RM, Marchioni DML, Colucci ACA. Avaliação do consumo alimentar e da ingestão de nutrientes na prática clínica. Ara Bras Endocrinol Metab. 2009;53(5):617-24. 